\title{
Expression of Growth and Hunger Related Genes and Physio-Biochemical Responses in Labeo rohita (Hamilton, 1822) Fed with Lysine and Betaine
}

\author{
Showkat Ahmad Dara Prem Prakash Srivastava ${ }^{a}$ Tincy Varghese ${ }^{a}$ \\ Subodh Gupta ${ }^{a}$ Gopal Krishna ${ }^{b}$ Pallath Muhammed Nuzaiba ${ }^{a}$ Tasok Leya \\ aDivision of Fish Nutrition, Physiology, and Biochemistry, ICAR-Central Institute of Fisheries Education, \\ Mumbai, India, ${ }^{b}$ Division of Fish Genetics and Biotechnology, ICAR-Central Institute of Fisheries \\ Education, Mumbai, India
}

\section{Key Words}

Lysine • Betaine • Ghrelin • Leptin • Growth Hormone Releasing Hormone • Insulin like Growth Factor $1 \cdot$ Enzymes analysis

\begin{abstract}
Background/Aims: The growth promoting effect of lysine and betaine as well as the expression of candidate genes reflecting their efficacy, such as ghrelin, leptin, Growth Hormone Secretagogue Receptor (GHS-R), Insulin like Growth Factor (IGF-1) and Growth Hormone Releasing Hormone (GHRH) was examined in Labeo rohita fingerlings. Methods: One hundred eighty healthy juveniles from a homologous population were randomly distributed to 15 rectangular tanks of 150 litres capacity. The experiment was carried out for 60 days with five treatment groups consisting T1 (0.25\% Betaine), T2 (0.5\% Betaine), T3 (0.75\% Lysine) and T4 (1.5\% Lysine) and control group. At the end of trial, the growth parameters such as weight gain, SGR, PER were estimated from the weight of the triplicate groups. The digestive, metabolic and antioxidant enzymes were analysed using spectrophotometric methods. The intestine, brain and liver were sampled from the treatments and expression of different genes ghrelin, leptin, GHSR, IGF-1 and GHRH was also performed by realtime PCR. Results: A significant $(P<0.05)$ increase in weight gain, SGR, PER and lowest FCR was found in T4 group which was significantly $(p<0.05)$ different from other experimental groups. The highest mRNA expression levels of expression were found in T4 group which was similar to that of ghrelin gene mRNA of T2 group. The significantly $(p<0.05)$ highest GHSR, GHRH and IGF-1 gene expression levels were found in T4 treatment group compared to other groups. Conclusion: The present study reveals that the lysine and betaine stimulate growth and expression of
\end{abstract}




\section{Cellular Physiology Cell Physiol Biochem 2019;53:851-864

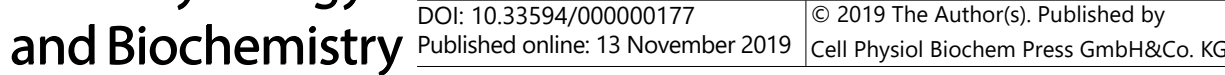 \\ Dar et al.: Effect of Lysine and Betaine on Molecular Expression of Growth in Labeo rohita}

ghrelin GHRH, GHS-R and IGF-1 genes. The increase of IGF-I mRNA expression with lysine and betaine supplementation revealed that these compounds act as growth modulators. However, lysine was found to be a more potent modulator of growth compared to betaine.

(c) 2019 The Author(s). Published by Cell Physiol Biochem Press GmbH\&Co. KG

\section{Introduction}

Many feed attractants are generally used in the diets of several fish species irrespective their nature of feeding. Lysine and betaine are important attractants and it is apparent that they increase feed consumption and growth in several fishes [1,2]. However, there is limited information on the mechanism by which they improve feed consumption and growth. Moreover, fish meal replacement still continues to be one of the most focussed research areas in fish nutrition. The seasonal and unreliable availability and the high cost of fish meal are the reasons for the feed industry to look towards the alternate protein sources to meet up the demand for fish feed. In general, feed ingredients from plant origin are not considered as the suitable protein source to replace fish meal, due to its imbalance in essential amino acid profile as required for the cultured species [3].

Lysine is one among the essential amino acid, which is deficient in most of the plant protein sources; hence it is necessary to supplement it in the plant based diet [4]. Lysine deficiency causes reduced growth and low feed efficiency as revealed in numerous fish species $[5,6,7]$ Besides, it is the most limiting amino acid in many available protein sources in fish feeds, especially plant proteins [8]. Betaine (trimethylglycine) is highly soluble in water, and therefore it can stimulate the olfactory bulb of fish. Betaine can be found in high quantities in marine invertebrates [9], micro-organisms and some plants [10]. Betaine application in aquafeed has increased during the last decade, often used as a feeding stimulant for several species of fish [11] to enhance the growth performance. The main physiological or metabolic functions of betaine are related to osmoregulation and methyl donation [12]. It is also reported to improve feed intake, and growth in plant-based diet fed fishes [13]. As lysine and betaine are two common additives used in aqua feed as feeding stimulants, it is important to study the comparative efficiency of the two with the help of appetite regulating factors.

The mechanism by which the feed intake is modulated mainly involves several hunger and growth related hormones. Ghrelin is a peptide hormone has essential roles in the control of food intake and metabolism. Ghrelin is known as a potent stimulator of food intake [14], and it increases body weight gain and adiposity in mammals $[15,16]$. The growth hormone release from the pituitary by ghrelin stimulation has been well characterized in mammals, birds, amphibians and teleost fish such as sea bream [17] rainbow trout [18], tilapia [19] and channel catfish [20]. Ghrelin has species-specific actions on food intake in fish [21]. It is also apparent that starvation induces ghrelin expression in Labeo rohita fingerlings [22]. $L$. rohita is a major carp, widely cultured throughout India owing to its high commercial value.

Growth rate is one of the most important parameters determining the economic efficiency of commercial fish culture, which is influenced by several biotic and abiotic factors [23]. Growth hormone secretion and action is mediated by insulin like growth factor-I [24]. Dietary ration, dietary protein content, and body growth rate in many fish species is positively correlated with blood levels of IGF-I or tissue levels of its mRNA [25]. Supplementation of fish feeds with lysine and betaine enhances protein deposition in the body $[26,27]$ and associated with nitrogen retention [28]. Thus, a research study was carried to see the effect of lysine and betaine on feeding and growth related gene responses in L. rohita. Further to reveal the effects on digestive, metabolic and physiological responses towards lysine and betaine supplemented diets. 


\section{Cellular Physiology Cell Physiol Biochem 2019;53:851-864 \\ \begin{tabular}{ll|l} 
and Biochemistyy & $\begin{array}{l}\text { DOI: 10.33594/000000177 } \\
\text { Published online: } 13 \text { November } 2019\end{array}$ & $\begin{array}{l}\text { C } 2019 \text { The Author(s). Published by } \\
\text { Cell Physiol Biochem Press GmbH\&Co. KG }\end{array}$
\end{tabular} \\ Dar et al.: Effect of Lysine and Betaine on Molecular Expression of Growth in Labeo rohita}

\section{Materials and Methods}

\section{Ethical statement}

The animals used in this work were cared and treated according to the procedures of the CPCSEA (Committee for the Purpose of Control and Supervision of Experiments on Animals), Ministry of Environment and Forests (Animal Welfare Division), Govt of India on care and use of animals in scientific research. All fish handling and treatment procedures were approved by the Ethics and Animal Care Committee of the Indian council of Agriculture research, Central Institute of Fisheries Education, (ICAR-CIFE), Mumbai-61 established norms

\section{Experimental design and sampling}

The experiment was conducted in the wet laboratory of Central Institute of Fisheries Education (CIFE), Mumbai, India, for a period of 60 days under controlled conditions. Fingerlings of $L$. rohita were collected from the local fish farm and acclimated for a week with preconditioning diet having 35\% dietary protein. The experiment consisted five treatments, viz., C (control group), T1 (0.25\% Betaine), T2 (0.5\% Betaine), T3 (0.75\% Lysine) and T4 (1.5\% Lysine) with three replicate each. The diet fed to control group (C) was prepared without lysine or betaine. One hundred eighty healthy juveniles from a homologous population were randomly distributed to 15 rectangular tanks of 150 litres capacity. Water exchange was done once in three days during experiment. The experimental diets were fed to the fishes twice a day ( 9.00 am and 4.00 $\mathrm{pm}$ ) up to satiation. The composition of experimental diet is given in Table 1. Fishes were weighed at 15 days interval during feeding trial. Tissues for RNA isolation and enzyme analysis were dissected out from fishes. Fishes were anaesthetized and tissues were collected from the fish from each replicate under sterile conditions and transferred in the RNA Later for gene expression analysis.

\section{Growth efficiency study}

Weighing of experimental animals was done in the wet laboratory itself using an electronic weighing balance. Growth parameters were calculated as follows,

Percent weight gain $=($ Wfinal - Winitial $) \times 100 /$ Winitial

Specific growth rate $($ SGR $)=(\ln$ Wfinal $-\ln$ Winitial $) \times 100 /$ number of days

Feed Conversion Ratio (FCR) = Feed given/ Wgain

Protein efficiency ratio $(\mathrm{PER})=\mathrm{Wgain} /$ Protein fed

Percentage survival rate $=$ total number harvested $\times 100 /$ total numbers stocked .

Proximate composition analysis

Experimental fishes

from each treatment groups were collected in triplicates and chopped for proximate composition analysis. The moisture content was analyzed by subtracting the weight before and after drying at $105^{\circ} \mathrm{C}$ for overnight. Ash content was analysed by burning the samples in muffle furnace at $500^{\circ} \mathrm{C}$ for 6 hours, percent crude protein (CP\%) and percent ether extract and (or) crude lipid were estimated by micro-Kjeldahl (nitrogen $\times 6.25$ ) and Soxlet extraction respectively. Percent crude fibre (CF \%)
Table 1. Feed formulation and composition of experimental diets fed to different experimental groups. ${ }^{1}$ Composition of vitamin mineral mix (Premix Plus) (quantity $/ \mathrm{kg}^{-1}$ ), Halver (1976). Vitamin A- 55,00,000 IU; Vitamin $\mathrm{D}_{3}-11,00,000 \mathrm{IU}$; Vitamin $\mathrm{B}_{2}-2,000 \mathrm{mg}$; Vitamin E- $750 \mathrm{mg}$; Vitamin K- 1,000 mg; Vitamin $\mathrm{B}_{6}-1,000 \mathrm{mg}$; Vitamin $\mathrm{B}_{12}-6$ mcg; Calcium Pantothenate- 2,500 mg; Nicotinamide- $10 \mathrm{~g}$; Choline Chloride- $150 \mathrm{~g}$; Mn27,000 mg; I- 1,000 mg; Fe- 7,500 mg; Zn- 5,000 mg; Cu- 2,000 mg; Co450; L- lysine- 10 g; DL-Methionine- $10 \mathrm{~g}$; Selenium- $125 \mathrm{mg}$

\begin{tabular}{|c|c|c|c|c|c|}
\hline Ingredients & $\begin{array}{c}\text { C } \\
\text { Control }\end{array}$ & $\begin{array}{c}\mathrm{T} 1 \\
\text { [Betaine(LD)] }\end{array}$ & $\begin{array}{c}\mathrm{T} 2 \\
\text { [Betaine (HD)] }\end{array}$ & $\begin{array}{c}\text { T3 } \\
\text { [Lysine (LD)] }\end{array}$ & $\begin{array}{c}\mathrm{T} 4 \\
\text { [Lysine (HD)] }\end{array}$ \\
\hline Casein & 32.2 & 32.2 & 32.2 & 32.2 & 32.2 \\
\hline Gelatin & 7.3 & 7.3 & 7.3 & 7.3 & 7.3 \\
\hline Dextrin & 17.75 & 17.75 & 17.75 & 17.75 & 17.75 \\
\hline Starch & 22.5 & 22.5 & 22.5 & 22.5 & 22.5 \\
\hline Cellulose & 10 & 9.75 & 9.5 & 9.25 & 8.5 \\
\hline Cod liver oil & 3 & 3 & 3 & 3 & 3 \\
\hline Sunflower oil & 3 & 3 & 3 & 3 & 3 \\
\hline Betaine & 0 & 0.25 & 0.5 & 0 & 0 \\
\hline Lysine & 0 & 0 & 0 & 0.75 & 1.5 \\
\hline Vit. Min.Premix ${ }^{1}$ & 2 & 2 & 2 & 2 & 2 \\
\hline $\mathrm{CMC}$ & 1.5 & 1.5 & 1.5 & 1.5 & 1.5 \\
\hline Choline chloride & 0.5 & 0.5 & 0.5 & 0.5 & 0.5 \\
\hline BHT & 0.25 & 0.25 & 0.25 & 0.25 & 0.25 \\
\hline Total & 100 & 100 & 100 & 100 & 100 \\
\hline
\end{tabular}




\section{Cellular Physiology Cell Physiol Biochem 2019;53:851-864 \\ \begin{tabular}{ll|l} 
and Bol: 10.33594/000000177 & O 2019 The Author(s). Published by \\
Cell Physiol Biochem Press GmbH\&Co. KG
\end{tabular} \\ Dar et al.: Effect of Lysine and Betaine on Molecular Expression of Growth in Labeo rohita}

was estimated by acid and alkali digestion. Nitrogen free extract was calculated by subtracting CP\%, EE\%, Ash $\%$ and CF\% from total dry matter content.

\section{Enzyme analysis}

Tissues such as liver, muscle and intestine were dissected out aseptically, weighed carefully and homogenised in chilled $0.25 \mathrm{M}$ sucrose solution in a glass tube using a Teflon-coated mechanical tissue homogenizer for enzyme analysis. The lysate was centrifuged at $7500 \times \mathrm{g}$ for 10 minutes at $4^{\circ} \mathrm{C}$ using a centrifuge machine and supernatant was stored in $-20^{\circ} \mathrm{C}$.

Amylase (E.C. 3.2.1.1) activity in the intestinal tissue was assayed with $2 \%(\mathrm{w} / \mathrm{v})$ starch solution in phosphate buffer ( $\mathrm{pH} 7$ ) as substrate [29]. The mixture was incubated at $37^{\circ} \mathrm{C}$ for 30 min and the reaction was stopped by the addition of dinitrosalicylic acid (DNS) and keeping in boiling water bath for 5 min. The reaction mixture was diluted with distilled water and absorbance recorded at $540 \mathrm{~nm}$. Activity was determined from maltose standard curve and expressed as mole of maltose released from starch per min per mg protein at $37^{\circ} \mathrm{C}$.

Lipase (E.C. 3.1.1.3) activity was measured by titrimetric method according to [30]. Reaction mixture consisting distilled water, tissue homogenate, phosphate buffer solution (pH 7) and olive oil emulsion was prepared by incubating it at $4{ }^{\circ} \mathrm{C}$ for $24 \mathrm{~h}$ in a shaking incubator. $95 \%$ alcohol and 2 drops of phenolphthalein indicators had been added before it was titrated against $0.05 \mathrm{~N} \mathrm{NaOH}$. The end point was recorded at the appearance of permanent pink colour in the mixture. A control was taken using enzyme source that was inactivated prior to addition of buffer and olive oil emulsion. The quantity of fatty acid released in unit time is measured by the quantity of $0.05 \mathrm{~N} \mathrm{NaOH}$ required to maintain constant $\mathrm{pH}$. The milliequivalent of alkali consumed is taken as a measure of the activity of the enzyme.

Protease activity was determined as described by [31]. The reaction mixture consisted of $1 \%$ casein in $0.05 \mathrm{M}$ Tris-P04 buffer ( $\mathrm{pH} 7.8$ ). The mixture was incubated for $5 \mathrm{~min}$ at $37^{\circ} \mathrm{C}$ and the tissue homogenate was then added. The reaction was stopped after 10 minutes by the addition of $10 \%$ TCA. The precipitate was filtered out and measured its absorbance at $280 \mathrm{~nm}$. A reagent blank was made by the addition of tissue homogenate to the mixture just before measuring the absorbance. One unit of enzyme activity was defined as the amount of enzyme needed to release acid-soluble fragments equivalent to $0.001 \mathrm{~A} 280$ per minute at $37^{\circ} \mathrm{C}$ and $\mathrm{pH} 7.8$.

The hexokinase (HK; EC 2.7.1.1) activity and glucose-6-phosphatase (G6Pase, E.C.3.1.3.9) activity were measured according to [32]. Hexokinase activity was measured by determining glucose-6-phosphate formed after the reaction [33] and G6Pase was measured according to [34]. In both the case, the stable phosphorus was estimated from the protein free supernatant according to the method of [35].

The glucose-6-phosphate dehydrogenase (G6PD, E.C.1.1.1.49) in the liver tissue was assayed by the method of [36]. The reaction mixture consisted of $1.5 \mathrm{ml}$ of $0.1 \mathrm{M}$ Tris buffer (pH 7.8), $0.2 \mathrm{ml}$ of $2.7 \mathrm{~mm}$ NADP, $0.1 \mathrm{ml}$ of $5 \%$ tissue homogenate, $1.05 \mathrm{ml}$ of distilled water and $50 \mu \mathrm{l}$ of $0.2 \mathrm{~m}$ G-6-P. The reaction was started by adding glucose 6-phosphate to the mixture. The OD was recorded at $340 \mathrm{~nm}$ at 15 seconds interval for $3 \mathrm{~min}$. The enzyme activity was expressed as units per $\mathrm{min} / \mathrm{mg}$ protein. One unit was equal to $\Delta 0.01 \mathrm{OD} 340 / \mathrm{min} / \mathrm{ml}$ at $37^{\circ} \mathrm{C}$. Lactate dehydrogenase (LDH; L-lactate NAD+ oxidoreductase: E.C. 1.1.1.27) was assayed by measuring the change in the absorbance of a reaction mixture containing sample at $340 \mathrm{~nm}$ for 3 minutes [37]. Superoxide dismutase (SOD; EC 1.15.1.1) and catalase (CAT; EC 1.11.1.6) activity were also measured by standard methods, [38] and [39] respectively.

\section{Gene expression study}

Total RNA Extraction and cDNA synthesis. Total RNA was extracted using TRIzol reagent (Invitrogen, USA) following manufatures instructions (guanidinium thiocyanate-phenol-chloroform extraction method). Isolated total RNA was quantified using spectrophotometer by measuring the absorbance at 260nm and evaluated visually on $1 \%$ agarose-ethidium bromide gels. The extracted RNA was treated with DNAse I (RNase free) to remove genomic DNA contamination. DNase treated mRNA transcripts were converted into cDNA strand using the Revert Aid first strand cDNA synthesis Kit (Fermentas, USA) by using oligo dT as primer. Coding sequences for the target genes of L. rohita were used for primer designing. The real time primers were designed in GeneRunner and given in Table 2. Conventional PCR was carried out to confirm the primers and conditions for real time PCR analysis. 
Quantitative Real-Time PCR ( $q R T-P C R$ ) and data analysis. qRT-PCR was performed with Roche, Agilant Ariamax real-time PCR system using DNA binding dye, SYBR green. Each $10 \mu$ reaction mixture contained $5 \mu$ l SYBR green PCR master mix (2x) (Fermentas, USA), $1 \mu$ l Forward and Reverse qRT-PCR Primer (Table 2; 2.5picomole), $15 \mathrm{ng}$ of template cDNA and nuclease free water. The conditions were 5 minutes hot start at 95 ${ }^{\circ} \mathrm{C}$ followed by 40 cycles of $15 \mathrm{~s}$ at $95^{\circ} \mathrm{C}, 30 \mathrm{~s}$ at $60^{\circ} \mathrm{Cand} 30 \mathrm{~s}$ at $72^{\circ} \mathrm{C}$ followed by melting curve analysis. The qRT-PCR analysis used $\beta$-actin as reference gene and zero days CT as external control. Analysis were done to three individuals from each treatment group in duplicates and the relative mRNA level was calculated by 2- $\Delta \Delta \mathrm{Ct}$ method, where $\Delta \Delta \mathrm{Ct}=(\mathrm{Ct}$, target gene- $\mathrm{Ct}$, internal control) 45th day - $(\mathrm{Ct}$, target gene-Ct, internal control) 0th day [40].

Statistical analysis. The statistical analyses were performed by using Statistical Package for the Social Sciences (SPSS) Version 22.0. Statistical differences among the five groups were analysed by oneway analysis of variance (ANOVA). Post-hoc comparisons between sample means were tested by Duncan's multiple range tests to determine the differences among treatment means at $p<0.05$. Values are expressed as mean \pm standard error.

\section{Results}

\section{Proximate composition of feed and water quality}

The proximate composition of different diets is presented in Table 2. There was no significant difference in protein concentration and energy values of all the experimental diets. Water quality parameters such as DO (4.92-5.31 $\left.\mathrm{mg} \mathrm{l}^{-1}\right)$, pH (7.7-7.9), hardness (236$242 \mathrm{mg} \mathrm{l}^{-1}$ as $\left.\mathrm{CaCo}_{3}\right)$, total ammonia $\left(<0.08 \mathrm{mgl}^{-1}\right)$, nitrate $\left(<0.9 \mathrm{mgl}^{-1}\right)$, nitrite $\left(<0.09 \mathrm{mgl}^{-1}\right)$ and water temperature $\left(28 \pm 0.4^{\circ} \mathrm{C}\right)$ were maintained throughout the period of experiment.

\section{Growth performance}

Significant $(\mathrm{p}<0.05)$ differences were found in weight gain $\%(W G)$, specific growth rate (SGR), feed conversion ratio (FCR), and protein efficiency ratio (PER) among the treatment groups are shown in Table 4. The highest weight gain was found in T4 group which was significantly ( $p<0.05$ ) different from other experimental groups. The lowest FCR was found in T4 group and highest in control group. SGR and PER was also found highest in T4 group which is significantly $(p<0.05)$ higher than the other treatment groups.

Table 2. Primers used for real time gene expression study

\begin{tabular}{lcc}
\hline Primer name & Sequence 5'-3' & NCBI Accession number \\
\hline$\beta$ - Actin F & CACTGCTGCTTCCTCCTCCCC & EU184877.1 \\
$\beta$ - Actin R & GATACCGCAAGACTCCATACCCA & \\
Ghrelin F & GAACTAAACCAGGTGACTTCCCA & LC271259 \\
Ghrelin R & TAATCACTGGGATCTCTGGCTC & \\
Leptin F & GCAGGCAGACACCATCATCCTC & KX241863 \\
Leptin R & CTTAGGGACTCCACGATAGACCCG & \\
GHSR - F & CAAAATACAAGGACATGCGAACC & LC331666 \\
GHSR- R & GCAACACTCGCTCACAAACTGAA & \\
IGF-I & TCGCGTTGACTCCCGCGACACTG & KX455870.1 \\
IGF-I & CCTTAGCTCACAGCTCTGAAAG & \\
GHRH-F & GTCAGCGACATCTTCTCCAGTAT & LC314790 \\
GHRH-R & GTTTGAAGGAATTTTCTGGCAGA & \\
\hline
\end{tabular}

Table 3. Proximate composition of feed (Dry matter basis). Note: Crude protein (CP), Ether extract (EE), Total Ash (TA), Crude Fibre(CF), Nitrogen Free Extract (NFE) and Digestable Energy (DE). Values in the same column with different superscripts letters are significantly different $(P<0.05)$. Values are presented as mean \pm SEM

\begin{tabular}{lccccc}
\hline Treatment & Control & T1 & T2 & T3 & T4 \\
\hline CP & $34.67 \pm 0.55$ & $34.45 \pm 1.53$ & $35.07 \pm 0.77$ & $35.1 \pm 1.01$ & $35.43 \pm 0.73$ \\
EE & $6.13 \pm 0.14$ & $5.86 \pm 0.22$ & $5.91 \pm 0.40$ & $6 \pm 0.36$ & $6.23 \pm 0.21$ \\
TA & $2.23 \pm 0.09$ & $2.24 \pm 0.13$ & $2.42 \pm 0.12$ & $2.19 \pm 0.17$ & $2.28 \pm 0.20$ \\
CF & $10.66 \pm 0.29$ & $10.25 \pm 0.14$ & $9.99 \pm 1.03$ & $10.12 \pm 0.76$ & $9.33 \pm 1.15$ \\
NFE & $46.52 \pm 0.52$ & $46.97 \pm 1.32$ & $46.59 \pm 2.04$ & $46.58 \pm 0.55$ & $46.71 \pm 1.83$ \\
DE (Kcal/100g) & $379.08 \pm 1.48$ & $379.35 \pm 1.36$ & $379.85 \pm 4.23$ & $380.74 \pm 5.37$ & $384.71 \pm 4.77$ \\
\hline
\end{tabular}


Fig. 1. Expression of ghrelin mRNA in the intestine of $L$. rohita with different treatment groups using real-time quantitative PCR, Each bar represents the mean \pm SE (n $=6$ ). Letters denote significant differences between the control group and treatment groups $(\mathrm{p}<0.05)$.

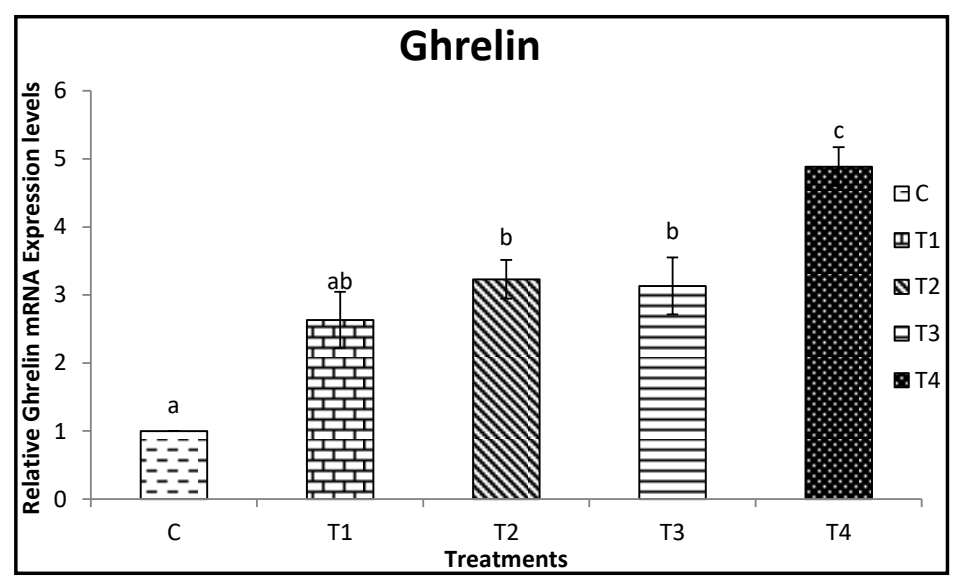

Fig. 2. Expression of Leptin mRNA in the liver of $L$. rohita with different treatment groups using real-time quantitative PCR, Each bar represents the mean \pm SE ( $n$ $=6$ ). Letters denote significant differences between the control group and treatment groups at each time point $(\mathrm{p}<0.05)$.

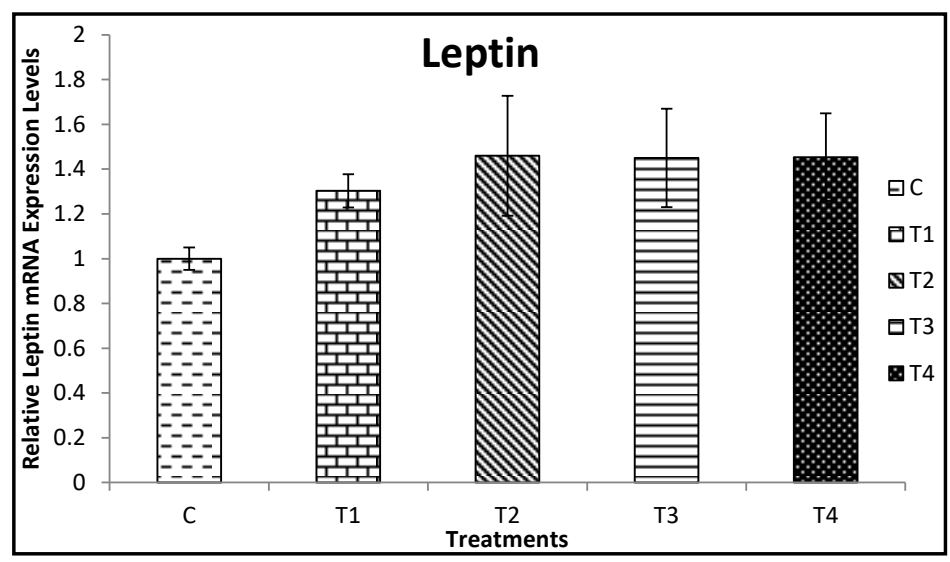

Fig. 3. Expression of GHS-R mRNA in the intestine of $L$. rohita with different treatment groups using real-time quantitative PCR, Each bar represents the mean \pm SE (n $=6)$. Letters denote significant differences between the control group and treatment groups $(\mathrm{p}<0.05)$.

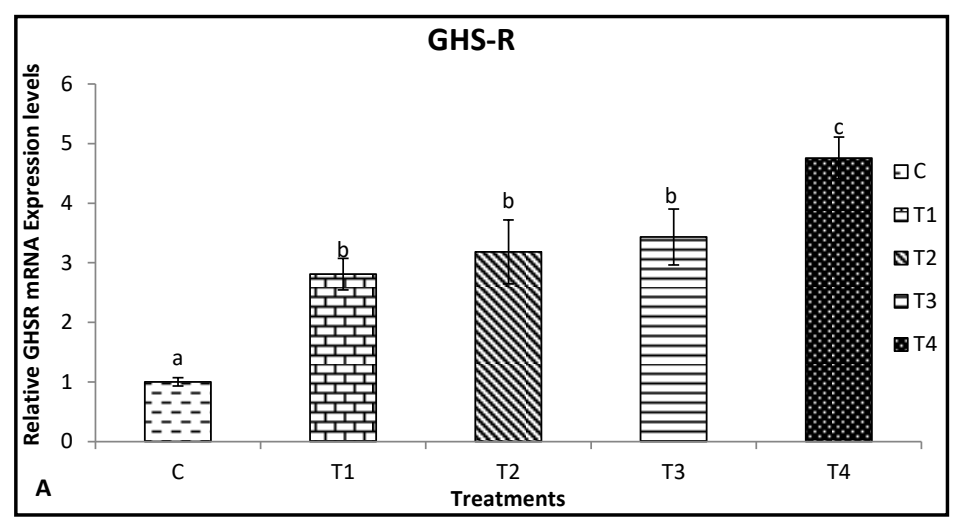

\section{Expression of ghrelin, leptin, GHSR, IGF- 1 and GHRH}

The expression studies of different genes ghrelin, leptin, GHSR, IGF- 1 and GHRH was carried out in different tissues such as liver, brain, intestine and muscle. The ghrelin mRNA expression was performed in intestine and is presented in Fig. 1. There was significant difference $(\mathrm{p}<0.05)$ in the ghrelin gene mRNA expression among the different treatment groups. The mRNA expression levels have increased significantly $(p<0.05)$ in the all the treatment groups compared to that of the control. The highest levels of expression were found in T4 group while the expression in T2 and T3 group was statistically similar. The leptin mRNA expression was carried out in liver and is shown in Fig. 2. No significant difference was found among the different treatment groups of the experiment. 
Fig. 4. Expression of GHRH mRNA in the brain of $L$. rohita with different treatment groups using real-time quantitative PCR, Each bar represents the mean \pm SE (n $=6$ ). Letters denote significant differences between the control group and treatment groups $(\mathrm{p}<0.05)$.

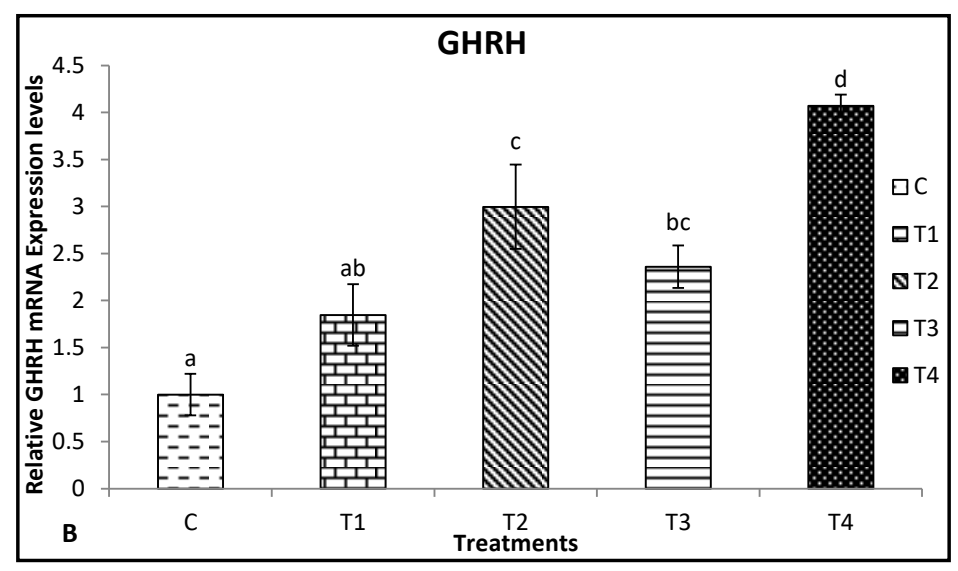

The GHSR gene mRNA expression levels were found in intestine and shown in Fig. 3. There were significant changes $(p<0.05)$ in the expression levels of GHSR gene among the different treatment groups. The significantly $(\mathrm{p}<0.05)$ highest GHSR gene expression levels were found in T4 treatment group compared to other groups. The changes in GHRH mRNA expression levels are presented in Fig. 4. The expression levels increased significantly $(p<0.05)$ in the different treatment groups from that of the control groups. The higher GHRH mRNA expression was found in $\mathrm{T} 2$ and $\mathrm{T} 4$ groups compared to the other groups of trial.

The expression studies of IGF-1 were carried out in liver and muscle tissues and the data is shown in Fig. 5 (A\&B) respectively. There was a significant difference $(\mathrm{p}<0.05)$ in IGF-1 gene

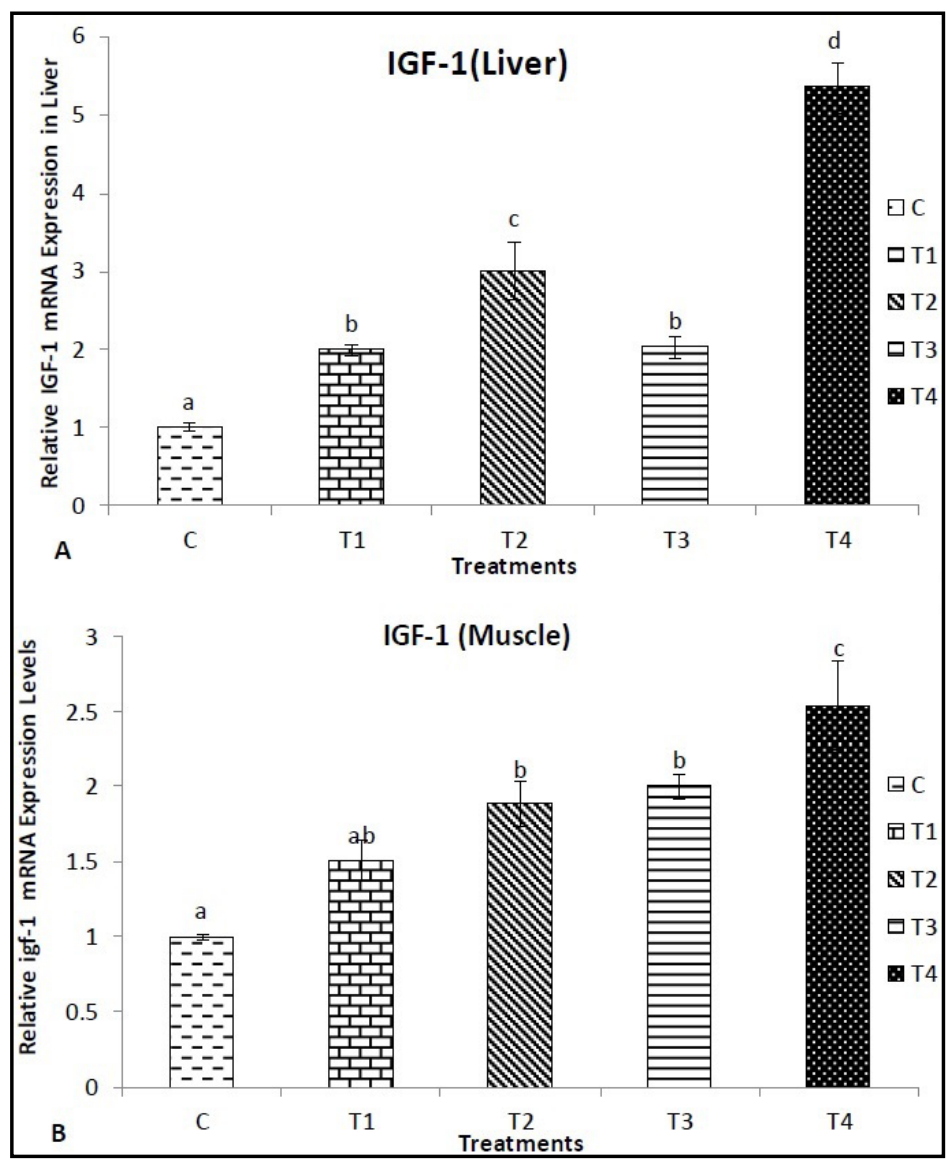

Fig. 5. Expression of IGF 1 mRNA in the (A) Liver and (B) muscle of $L$. rohita with different treatment groups using real-time quantitative PCR, Each bar represents the mean \pm SE $(n=6)$. Letters denote significant differences between the control group and treatment groups $(\mathrm{p}<0.05)$. mRNA expression levels among treatment groups in both the tissues. The hepatic expression levels of IGF-1 increased significantly $(p<0.05)$ in the treatment groups compared to the control group. The significantly $(\mathrm{p}<0.05)$ highest hepatic expression levels of IGF-1 gene was found in T4 group among the experimental groups. The IGF-1 expression levels in the muscle also varied significantly, with highest $(\mathrm{p}<0.05)$ expression levels at the T4 group of the experiment. During the experimental trial, there 
was a significant $(\mathrm{P}<0.05)$ increase in serum ghrelin levels (Fig. 6). Significant difference $(p<0.05)$ was found between T4 and other experimental groups. The highest ghrelin serum levels were found in $\mathrm{T} 4$ group.

\section{Digestive enzyme assay}

The digestive enzyme activity of protease, amylase and lipase is presented in Table 5. The protease activity was significantly higher $(\mathrm{p}<0.05)$ in the T4 and T2 groups compared to the other groups. The amylase activity was also significantly $(\mathrm{p}<0.05)$ different among the various treatment groups. The highest $(\mathrm{p}<0.05)$ amylase activity was found in $\mathrm{T} 3$ group compared to other treatment groups. The activity of lipase enzymes did not vary significantly $(\mathrm{p}<0.05)$ among different treatment groups.

\section{Metabolic enzyme assay}

The activities of metabolic enzymes such as hexokinase, glucose-6-phosphatase (G6Pase), glucose-6-phosphate dehydrogenase (G6PDH), lactate dehydrogenase (LDH), aspartate amino transferase (AST), alanine amino transferase (ALT) in liver of L. rohita is shown in Table 6. The hexokinase activity was found significantly $(\mathrm{p}<0.05)$ different among the various treatment groups. The highest hexokinase activity was found in the T2 group compared to that of the control group. The hexokinase activity of other groups was in similar to that of $\mathrm{T} 2$ group. No significant difference was found in G6Pase and G6PDH activities among the different treatments. LDH activity was found significantly $\quad(\mathrm{p}<0.05)$ different among the various treatment groups. The highest LDH activity was observed in the T2 group which was similar to that of T3 and T4 groups. The lowest activity was found in $\mathrm{T} 1$ group compared to other treatments. AST and

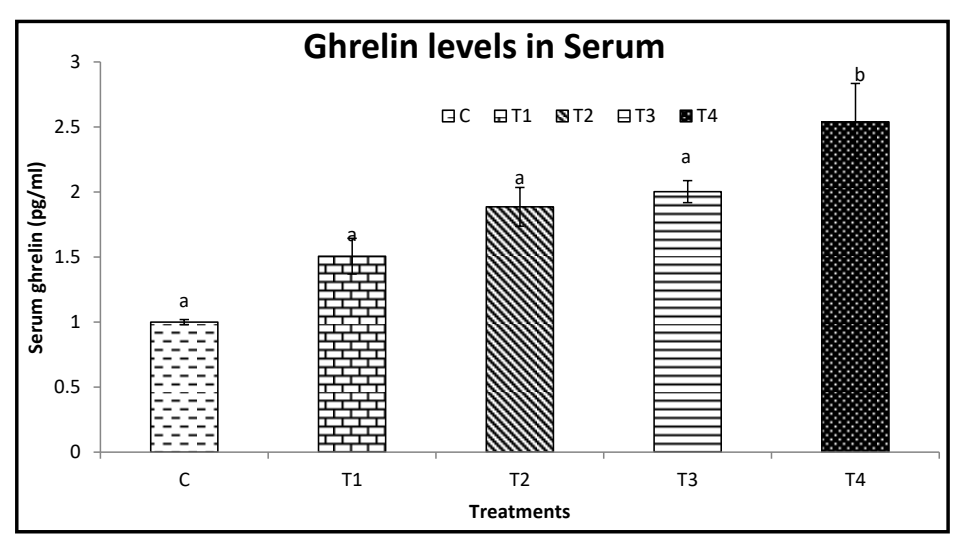

Fig. 6. Serum ghrelin levels present in L. rohita Fingerlings of different treatment groups. Each bar represents the mean \pm SE $(n=6)$. Letters denote significant differences between the control group and treatment groups $(\mathrm{p}<0.05)$.

Table 4. Effect of different growth modulators on the growth Performance of $L$. rohita. Note: Percent weight gain (\%WG); specific growth rate (SGR); Feed Conversion Ratio (FCR) and Protein Efficiency Ratio (PER). Values in the same column with different superscripts letters are significantly different $(\mathrm{P}<0.05)$. Values are presented as mean \pm SEM

\begin{tabular}{lcccc}
\hline Treatments & $(\% \mathrm{WG})$ & FCR & SGR & PER \\
\hline Control & $59.01^{\mathrm{a}} \pm 3.61$ & $3.66^{\mathrm{c}} \pm 0.32$ & $0.250^{\mathrm{a}} \pm 0.02$ & $0.79^{\mathrm{a}} \pm 0.06$ \\
T1 & $63.33^{\mathrm{a}} \pm 1.20$ & $3.58^{\mathrm{c}} \pm 0.11$ & $0.253^{\mathrm{a}} \pm 0.01$ & $0.79^{\mathrm{a}} \pm 0.02$ \\
T2 & $82.03^{\mathrm{c}} \pm 1.15$ & $2.65^{\mathrm{ab} \pm 0.13}$ & $0.325^{\mathrm{b} \pm 0.01}$ & $1.08^{\mathrm{b}} \pm 0.06$ \\
T3 & $73.16^{\mathrm{b} \pm 1.01}$ & $3.04^{\mathrm{b} \pm 0.04}$ & $0.298^{\mathrm{b}} \pm 0.01$ & $1.04^{\mathrm{b} \pm 0.03}$ \\
T4 & $97.46^{\mathrm{d}} \pm 0.29$ & $2.21^{\mathrm{a}} \pm 0.06$ & $0.365^{\mathrm{c}} \pm 0.02$ & $1.27^{\mathrm{c}} \pm 0.03$ \\
\hline
\end{tabular}

Table 5. Digestive enzyme activities for the different experimental groups. Data expressed as Mean \pm SE, $\mathrm{n}=3$; mean values in the same row with different superscripts differ significantly $(\mathrm{P}<0.05)$. Activities are expressed as follows, ${ }^{1}$ Activity expressed as micromoles of tyrosine released $/ \mathrm{min} / \mathrm{mg}$ protein. ${ }^{2}$ Activity expressed as micromoles of maltose released $/ \mathrm{min} / \mathrm{mg}$ protein. ${ }^{3}$ Activity expressed as units $/ \mathrm{mg}$ protein

\begin{tabular}{lccccc}
\hline Treatments & Control & $\mathrm{T} 1$ & $\mathrm{~T} 2$ & $\mathrm{~T} 3$ & $\mathrm{~T} 4$ \\
\hline Protease $^{1}$ & $11.18^{\mathrm{a}} \pm 0.72$ & $12.44^{\mathrm{ab} \pm 0.33}$ & $13.71^{\mathrm{b} \pm 0.65}$ & $12.444^{\mathrm{ab} \pm 0.57}$ & $13.85^{\mathrm{b} \pm 0.23}$ \\
Amylase $^{2}$ & $10.22^{\mathrm{a}} \pm 0.69$ & $10.4^{\mathrm{ab} \pm 0.69}$ & $13.59 \mathrm{c} \pm 0.52$ & $11.77^{\mathrm{abc} \pm 0.70}$ & $12.67 \mathrm{bc} \pm 0.94$ \\
Lipase $^{3}$ & $0.26 \pm 0.03$ & $0.28 \pm 0.05$ & $0.38 \pm 0.03$ & $0.25 \pm 0.05$ & $0.27 \pm 0.07$ \\
\hline
\end{tabular}


Table 6. Metabolic Enzyme activities for the different experimental groups. Data expressed as Mean $\pm \mathrm{SE}$, $\mathrm{n}=3$; mean values in the same row with different superscripts differ significantly $(\mathrm{P}<0.05) .{ }^{1}$ Hexokinase: milli units/min/mg protein. ${ }^{2}$ Glucose-6-phosphatase (G6Pase): expressed as $\mu$ g phosphorus released/min/ mg protein at $37^{\circ} \mathrm{C} .{ }^{3} \mathrm{G} 6 \mathrm{PDH}$ : expressed as units $/ \mathrm{min} / \mathrm{mg}$ protein at $37^{\circ} \mathrm{C}$. ${ }^{4}$ Lactate dehydrogenase (LDH): expressed as units $/ \mathrm{min} / \mathrm{mg}$ protein at $37^{\circ} \mathrm{C} .{ }^{5}$ Aspartate amino transferase: $\eta$ moles of oxaloacetate released/ $\mathrm{min} / \mathrm{mg}$ protein. ${ }^{6}$ Alanine amino transferase: $\eta$ moles of sodium pyruvate released $/ \mathrm{min} / \mathrm{mg}$ protein

\begin{tabular}{lccccc}
\hline Treatments & Control & $\mathrm{T} 1$ & $\mathrm{~T} 2$ & $\mathrm{~T} 3$ & $\mathrm{~T} 4$ \\
\hline Hexokinase $^{1}$ & $67.48^{\mathrm{a}} \pm 1.16$ & $68.15^{\mathrm{ab}} \pm 2.31$ & $74.18^{\mathrm{b}} \pm 1.19$ & $68.78^{\mathrm{ab} \pm 1.43}$ & $72.78^{\mathrm{ab} \pm 2.64}$ \\
G6Pase $^{2}$ & $0.193 \pm 0.01$ & $0.197 \pm 0.01$ & $0.196 \pm 0.02$ & $0.187 \pm 0.01$ & $0.198 \pm 0.02$ \\
G6PDH $^{3}$ & $264.66 \pm 8.45$ & $285.66 \pm 6.12$ & $258.01 \pm 16.26$ & $276.66 \pm 5.78$ & $274.33 \pm 10.27$ \\
LDH $^{4}$ & $175.22^{\mathrm{ab} \pm 5.98}$ & $162.37^{\mathrm{a}} \pm 3.75$ & $190.44 \mathrm{~b} \pm 3.80$ & $185.26^{\mathrm{b} \pm 2.98}$ & $188.34^{\mathrm{b} \pm 7.23}$ \\
AST $^{5}$ & $10.95^{\mathrm{a} \pm 0.45}$ & $12.06^{\mathrm{ab} \pm 1.098}$ & $13.71^{\mathrm{bc} \pm 0.67}$ & $11.93^{\mathrm{ab} \pm 0.57}$ & $14.38^{\mathrm{c}} \pm 0.95$ \\
ALT $^{6}$ & $10.33^{\mathrm{a}} \pm 1.03$ & $10.64^{\mathrm{a} \pm 0.11}$ & $12.89^{\mathrm{bc} \pm 0.78}$ & $11.30^{\mathrm{ab} \pm 1.12}$ & $14.28^{\mathrm{c}} \pm 0.97$ \\
\hline
\end{tabular}

Table 7. Superoxide Dismutase (SOD) and Catalase activity for the different experimental groups. Data expressed as Mean \pm SE $n=3$; Mean values bearing different superscripts in the same rows vary significantly $(\mathrm{p}<0.05)$. SOD Specific activity is expressed in $50 \%$ inhibition of epinephrine auto oxidation/mg protein/ minute. Specific activity of catalase expressed in nano moles $\mathrm{H}_{2} \mathrm{O}_{2}$ decomposed /minute /mg protein

\begin{tabular}{lccccc}
\hline Treatments(unit/mg protein) & Control & T1 & T2 & T3 & T4 \\
\hline SOD (Liver) & $51.1 \pm 5.75$ & $53.66 \pm 2.11$ & $53.11 \pm 2.45$ & $51.96 \pm 1.90$ & $51.36 \pm 1.40$ \\
SOD (Gill) & $47.79 \pm 2.36$ & $45.71 \pm 2.65$ & $47.46 \pm 1.16$ & $48.98 \pm 1.42$ & $50.21 \pm 4.43$ \\
Catalase (Liver) & $12.08 \pm 0.43$ & $11.47 \pm 0.93$ & $11.54 \pm 0.36$ & $11.72 \pm 0.54$ & $11.27 \pm 0.30$ \\
Catalase (Gill) & $10.19 \pm 0.27$ & $11.07 \pm 0.39$ & $10.67 \pm 1.11$ & $10.30 \pm 0.55$ & $9.47 \pm 0.34$ \\
\hline
\end{tabular}

ALT activities were significantly $(\mathrm{p}<0.05)$ different among the various groups. The highest $(\mathrm{p}<0.05)$ ALT and AST activity was found in T4 group of the experiment compared to other groups.

\section{Antioxidant enzyme activities}

The SOD and Catalase enzyme activities of liver and gill are present in Table 7. There was no significant difference in SOD and catalase activities of different treatments of this experiment.

\section{Discussion}

The experiment was carried out to know the effect of betaine and lysine on growth performance of L. rohita. Earlier studies designed to elucidate the effect of betaine were carried out in common carp [41], blunt snout bream [42], juvenile grouper [43] and pike perch [44]. Similarly, the effect of lysine on growth performance was investigated by several researchers in fishes such as African catfish [26], bream abramis [45] and sea bass [46]. However, the effect of betaine on the expression of endocrine marker genes was not studied earlier. In the present study, supplementation of lysine at any dose in the diet improved the PER and the feed conversion ratio FCR. The highest weight gain and lowest FCR were observed with $1.5 \%$ lysine supplementation. Our findings are similar with findings of [46] in sea bass who found highest growth with this level of lysine in diet comparable to other levels. This growth promoting effect may be due to the enhancement of protein synthesis. In addition, carbohydrate utilisation improved by the insulin secretagogue action of lysine. Our findings are supported by [47] who reported the increase in growth rate and PER when fed with lysine in black seabream [48] reported that 1.5-2.0\% dietary lysine increased weight gain of fingerling striped bass. Also, [49] determined the dietary lysine requirement of Atlantic salmon and found that fish fed diets containing low levels of lysine showed reduced feed utilization. In the present investigation, the group supplemented with betaine at $0.5 \%$ showed better growth compared to that of $0.25 \%$ and control. These results are supported 
by [50], who conducted a study in Oreochromis nilotica which exhibited better growth and lower FCR when fed with $0.5 \%$ betaine in diet [43]. also found that better weight gain and lower FCR for the betaine fed groups than the group fed with betaine free diet in juvenile grouper.

In present study, the effect of different levels of betaine and lysine on expression of different genes was carried out and the tissues were selected on the basis of their primary origin. The earlier report on the effect of lysine on ghrelin in in guinea fowl was studied by [51]. The present study reveals that the lysine stimulates the increase in the expression of ghrelin gene. Our study was supported by [51] in guinea fowl who found that lysine cause the increase in the expression of ghrelin gene. According to [52] lysine stimulates the anabolic hormones through ghrelin signalling in Salmo salar which would increase food intake. In our study, we did not find any significant effects of lysine on leptin level. However, earlier study by [51] reported that lysine levels affected leptin receptor expression in both the liver and brain, however there are no published data on the effect of lysine on leptin.

The effects of lysine and betaine levels on GHS- R and GHRH were studied. Our study found that the GHS-R gene expression level was increased under the influence of lysine. These results were supported by [52] who found that lysine causes the increase GHS-R expression in Salmo salar. There is hardly any published report on effect of lysine on ghrelin receptor (GHSR). The current research suggested that the ghrelin level increases due to lysine which in turn causes increase in GHS-R. According to researcher [53] Ghrelin was first identified as the endogenous ligand to an "orphan" receptor, the growth hormone secretagogue-receptor (GHS-R), and thus a potent stimulator of pituitary GH release in rat and human [53]. Hence, the increase in ghrelin expression levels causes increase in GSH-R expression supplemented with $1.5 \%$ lysine in diet. In present study, the GHRH expression levels was found highest in T4 treatment fed with high dose of Lysine. Our results are supported by investigator [52] who found increase in growth hormone with the lysine supplementation in Salmon salar. Further, a growth study with gilthead sea bream (Sparus aurata) revealed significantly lower GHs-R mRNA levels were present in fish fed a diet of plant protein containing slightly lower dietary lysine $(7.0 \mathrm{~g} / 16 \mathrm{~g} \mathrm{~N})$ as compared to those fed a fish meal diet with slightly higher lysine content ( $8.6 \mathrm{~g}$ Lys/16 g N) [54].

The effect of lysine and betaine on IGF-1 gene expression was carried out to know the effect of lysine on the IGF-1 response of $L$. rohita. The present study revealed that lysine causes increase in IGF-1 gene expression levels. Earlier reports by [52] suggested that dietary lysine nutrient caused an increase in the IGF-1 gene expression. The expression studies were carried out in both liver and muscle and highest IGF-1 gene expression was found in the liver. These results are supported by [55] who found that highest IGF-I mRNA levels were expressed in liver compared to muscle. The abundance of IGF-I mRNA in fish liver indicates that the liver has the highest transcriptional levels of this gene, having great impact on the regulation of muscle growth. Further, [56] reported that lysine deficiency is well documented to have a negative effect on growth and feed intake. Chicken fed low levels of lysine showed significantly lower growth, feed intake and plasma levels of IGF-I compared to those fed with optimum levels of lysine [57]. also suggested that the Lysine intake increased significantly with increased dietary Lys content, so the observed effects appear to be the result of dietary Lysine content, rather than feed intake per se. A higher Lysine intake increased the nitrogen deposition and muscle nitrogen accretion when compared with a low and medium lysine fed salmon.

The results of the present study demonstrated that lysine and betaine levels have influenced the activities of the digestive and metabolic enzymes of $L$. rohita fingerlings to some extent. In our study the digestive enzyme protease and amylase activities increased with the higher levels of lysine in diet suggesting lysine supplementation improved the activities of digestive enzymes of $L$. rohita. The increase in protease and amylase activities with lysine was suggested by earlier reports also. In larvae gilthead seabream, lysine served as stimulant to release trypsinogen in pancreas [58] [56]. reported that lysine increases the amylase activities in chicken. Further, study by [59] indicated that dietary lysine improves 
digestive enzyme and brush-border membrane enzyme activities of grass carp. In the present study, the lipase activities were not significantly different among the different groups. There are not earlier reports of effect of lysine on lipase activity; however, one of the recent reports by [42] found betaine causes increase in lipase activity in blunt snout bream. Increase in serum ghrelin levels were found in T4 group having 1.5\% Lysine supplementation compared to control. Our results were supported by [43] who reported lysine supplementation increase GH levels in serum of guinea fowl and no other study have been carried regarding effect of lysine or betaine on serum ghrelin levels.

In our present study, the effect of growth modulators on the activities of key enzymes involved in hepatic intermediary metabolism, such as hexokinase, G6Pase, AST, ALT, LDH and G6PDH was measured. No significant differences were found in G6Pase and G6PDH enzyme activities due to lysine and betaine supplementation. No earlier reports on G6Pase and G6PDH enzyme activities were present on effects of betaine and lysine levels on activities of these enzymes. Both ALT and AST are important amino transferases in mitochondria of fish, and their activity is closely associated with the metabolism of amino acids [59]. In present study, the AST and ALT levels were increased in 1.5\% lysine supplemented group compared to control as a result of higher concentration of free amino acid lysine in the diet. This result is further supported by the study of [60] who reported that the supplementation of lysine to juvenile black seabream resulted in the increase of hepatic AST and ALT activities. The increase in amino acid catabolism suggested by enhanced aminotransferase activities in the present study would further explain the increase in dietary protein utilization efficiency and enhanced protein synthesis and growth. CAT and SOD are the antioxidant enzymes responsible for the elimination of peroxides, hence protecting tissues against oxidative damage [61]. There were no significant changes observed in SOD and CAT enzyme activity revealing that the lysine and betaine supplementation did not cause any change in the oxidative status of the studied fish species.

\section{Conclusion}

The present study was carried out to know the effect of lysine and betaine on the endocrine regulation of growth and feeding behaviour. The present study reveals that the lysine stimulates the increase in the expression of ghrelin while there was no significant variation in leptin expression levels. However, it is found that the GHS-R gene expression level was increased under the influence of lysine and betaine along with GHRH and IGF1 genes. The significant increase in expression of genes related to the GH-IGF system (i.e. Ghrelin, GHS-R, GHRH and IGF-I in L. rohita fed with betaine and lysine supplemented diet significantly up-regulated growth in fishes. These endocrine responses also correlated with activity of metabolic and digestive enzymes. Our study proved that lysine and betaine act as growth modulators. A supplementation of $1.5 \%$ lysine is better than the $0.5 \%$ of betaine supplementation for favourable modulation of endocrine responses towards growth.

\section{Acknowledgements}

The authors are grateful to the Director, ICAR-Central Institute of Fisheries Education, Mumbai, India for providing all the necessary facilities and fund for carrying out the research work. The research article is a part of $\mathrm{PhD}$ thesis of the first author.

\section{Disclosure Statement}

The authors report no conflict of interest. 


\section{Cellular Physiology Cell Physiol Biochem 2019;53:851-864

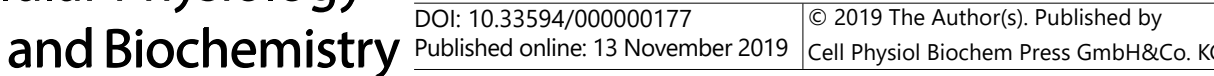 \\ Dar et al.: Effect of Lysine and Betaine on Molecular Expression of Growth in Labeo rohita}

\section{References}

1 Papatryphon E, Soares Jr JH: Identification of feeding stimulants for striped bass, Morone saxatilis. Aquaculture 2000;185:339-352.

2 Nguyen L, Davis DA: Comparison of crystalline lysine and intact lysine used as a supplement in practical diets of channel catfish (Ictalurus punctatus) and Nile tilapia (Oreochromis niloticus). Aquaculture 2016;464:331-339.

3 Akiyama DM: Soybean meal utilization by marine shrimp, in Applewhite TH (ed): Proceeding of the World Congress. Vegetable Protein Utilization in Human Foods and Animal Feedstuffs. Champaign, Illinois, American Oil Chemists Society, 1989, pp 252-265.

4 Cheng ZJ, Hardy RW, Usry JL: Effects of lysine supplementation in plant protein-based diets on the performance of rainbow trout (Oncorhynchus mykiss) and apparent digestibility coefficients of nutrients. Aquaculture 2003;215:255-265.

5 Ahmed I, Khan MA: Dietary lysine requirement of fingerling Indian major carp, Cirrhinus mrigala (Hamilton). Aquaculture 2004;235:499-511.

6 Wang S, Liu YJ, Tian LX, Xie MQ, Yang HJ, Wang Y, Liang GY: Quantitative dietary lysine requirement of juvenile grass carp Ctenopharyngodon idella. Aquaculture 2005;249:419-429.

7 Zhou XQ, Zhao CR, Jiang J, Feng L, Liu Y: Dietary lysine requirement of juvenile Jian carp (Cyprinus carpio var. Jian). Aquac Nutr 2008;14:381-386.

8 Deng D-F, Dominy W, Ju ZY, Koshio S, Murashige R, Wilson RP: Dietary lysine requirement of juvenile Pacific threadfin (Polydactylus sexfilis). Aquaculture 2010;308:44-48.

9 Polat A, Beklevik G: The importance of betaine and some attractive substances as fish feed additives; in Brufau J, Tacon A (eds): Feed manufacturing in the Mediterranean region: Recent advances in research and technology. Cahiers Options Méditerranéennes, vol 37. Zaragoza, CIHEAM, 1999, pp 217-220.

10 Zeisel SH, Mar MH, Howe JC, Holden JM: Concentrations of choline-containing compounds and betaine in common foods. J Nutr 2003;133:1302-1307.

11 Xue M, Cui Y: Effect of several feeding stimulants on diet preference by juvenile gibel carp (Carassius auratus gibelio), fed diets with or without partial replacement of fish meal by meat and bone meal. Aquaculture 2001;198:281-292.

12 Simon J: Choline, betaine and methionine interactions in chickens, pigs and fish (including crustaceans). Worlds Poult Sci J 1999;55:353-374.

13 Hoffman JR, Ratamess NA, Kang J, Rashti SL, Faigenbaum AD: Effect of betaine supplementation on power performance and fatigue. J Int Soc Sports Nutr 2009;6:7.

14 Toshinai K, Date Y, Murakami N, Shimada M, Mondal MS, Shimbara T, Guan JL, Wang QP, Funahashi H, Sakurai T: Ghrelin-induced food intake is mediated via the orexin pathway. Endocrinology 2003;144:15061512.

15 Kamegai J, Tamura H, Shimizu T, Ishii S, Sugihara H, Wakabayashi I: Chronic central infusion of ghrelin increases hypothalamic neuropeptide $\mathrm{Y}$ and Agouti-related protein mRNA levels and body weight in rats. Diabetes 2001;50:2438-2443.

16 Nakazato M, Murakami N, Date Y, Kojima M, Matsuo H, Kangawa K, Matsukura S: A role for ghrelin in the central regulation of feeding. Nature 2001;409:194.

17 Chan $\mathrm{CB}$, Cheng $\mathrm{CH}$ : Identification and functional characterization of two alternatively spliced growth hormone secretagogue receptor transcripts from the pituitary of black seabream Acanthopagrus schlegeli. Mol Cell Endocrinol 2004;214:81-95.

18 Shepherd BS, Johnson JK, Silverstein JT, Parhar IS, Vijayan MM, McGuire A, Weber GM: Endocrine and orexigenic actions of growth hormone secretagogues in rainbow trout (Oncorhynchus mykiss). Comp Biochem Physiol A Mol Integr Physiol 2007;146:390-399.

19 Riley LG, Fox BK, Kaiya H, Hirano T, Grau EG: Long-term treatment of ghrelin stimulates feeding, fat deposition, and alters the GH/IGF-I axis in the tilapia, Oreochromis mossambicus. Gen Comp Endocrinol 2005;142:234-240.

20 Won ET, Borski RJ: Endocrine regulation of compensatory growth in fish. Front Endocrinol (Lausanne) 2013;4:74.

21 Jönsson E: The role of ghrelin in energy balance regulation in fish. Gen Comp Endocrinol 2013;187:79-85. 


\section{Cellular Physiology Cell Physiol Biochem 2019;53:851-864

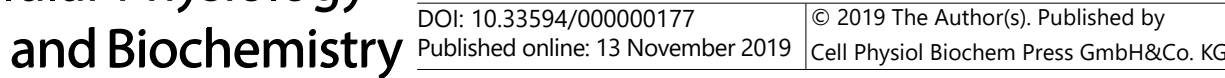 \\ Dar et al.: Effect of Lysine and Betaine on Molecular Expression of Growth in Labeo rohita}

22 Dar SA, Srivastava PP, Varghese T, Gupta S, Gireesh-Babu P, Krishna G: Effects of starvation and refeeding on expression of ghrelin and leptin gene with variations in metabolic parameters in Labeo rohita fingerlings. Aquaculture 2018;484:219-227.

23 Brett J, Groves TDD: Physiological energetics, in Hoar WS, Randall DJ, Brett JR (eds): Fish physiology: Bioenergetics and Growth. Orlando, Academic Press, Elsevier, 1979, vol 8, pp 279-352.

24 Björnsson BT, Johansson V, Benedet S, Einarsdottir IE, Hildahl J, Agustsson T, Jönsson E: Growth hormone endocrinology of salmonids: regulatory mechanisms and mode of action. Fish Physiol Biochem 2002;27:227-242.

25 Beckman BR, Shimizu M, Gadberry BA, Cooper KA: Response of the somatotropic axis of juvenile coho salmon to alterations in plane of nutrition with an analysis of the relationships among growth rate and circulating IGF-I and 41 kDa IGFBP. Gen Comp Endocrinol 2004;135:334-344.

26 Hamid SNIN, Abdullah MF, Zakaria Z, Yusof SJHM, Abdullah R: Formulation of fish feed with optimum protein-bound lysine for African catfish (Clarias gariepinus) fingerlings. Procedia engineering 2016;148:361-369.

27 Wu G, Davis DA: Interrelationship Among Methionine, Choline, and Betaine in Channel Catfish Ictalurus punctutus. J World Aquacult Soc 2005;36:337-345.

28 Cao J, Chen Y, Zhu X, Huang Y, Zhao H, Li G, Lan H, Chen B, Pan Q: A study on dietary L-lysine requirement of juvenile yellow catfish Pelteobagrus fulvidraco. Aquac Nutr 2012;18:35-45.

29 Rick W, Stegbauer HP: $\alpha$-Amylase measurement of reducing groups, in Bergermeyer HU (ed): Methods of Enzymatic Analysis, Verlag Chemie, Weinheim, 1974, ed 2, vol 2, pp 885-890.

30 Cherry IS, Crandall LA, Jr: The specificity of pancreatic lipase: its appearance in the blood after pancreatic injury. Am J Physiol 1932;100:266-273.

31 Drapeau GR, Boily Y, Houmard J: Purification and properties of an extracellular protease of Staphylococcus aureus. J Biol Chem 1972;247:6720-6726.

32 Alexander C, Sahu N, Pal A, Akhtar M, Saravanan S, Xavier B, Munilkumar S: Higher water temperature enhances dietary carbohydrate utilization and growth performance in Labeo rohita (Hamilton) fingerlings. J Anim Physiol Anim Nutr (Berl) 2011;95:642-652.

33 Crane RK, Sols A: [33] Animal tissue hexokinases:(Soluble and particulate forms) Hexose+ ATP $\rightarrow$ Hexose6-P+ ADP; in Colowick SP, Kaplan NO (eds): Methods in Enzymology. New York, Academic Press, 1955, vol 1, pp 277-282.

34 Swanson MA: [83] Glucose-6-phosphatase from liver; in Colowick SP, Kaplan NO (eds): Methods in Enzymology. New York, Academic Press, 1955, vol 2, pp 541-543.

35 Fiske CH, Subbarow Y: The colorimetric determination of phosphorus. J Biol Chem 1925;66:375-400.

36 Löhr GW, Waller HD: Glucose-6-phosphate Dehydrogenase:(Zwischenferment); in Bergmeyer HU (ed): Methods of Enzymatic Analysis, Verlag Chemie, Weinheim, 1965, pp 744-751.

37 Akhtar MS, Pal AK, Sahu NP, Alexander C, Gupta SK, Choudhary AK, Jha AK, Rajan MG: Stress mitigating and immunomodulatory effect of dietary pyridoxine in Labeo rohita (Hamilton) fingerlings. Aquac Res 2010;41:991-1002.

38 Misra HP, Fridovich I: The univalent reduction of oxygen by reduced flavins and quinones. J Biol Chem 1972;247:188-192.

39 Takahara S, Hamilton HB, Neel JV, Kobara TY, Ogura Y, Nishimura ET: Hypocatalasemia: a new genetic carrier state. J Clin Invest 1960;39:610-619.

40 Livak KJ, Schmittgen TD: Analysis of relative gene expression data using real-time quantitative PCR and the 2- $\Delta \Delta$ CT method. Methods 2001;25:402-408.

41 Ali HHA, AL-Faragi JK: Efficiency of betaine and $\beta$-glucan as feed additives on the growth performance and survival rate of common carp (Cyprinus carpio L.) fingerlings. J Entomol Zool Stud 2017;5:27-31.

42 Adjoumani JJY, Wang K, Zhou M, Liu W, Zhang D: Effect of dietary betaine on growth performance, antioxidant capacity and lipid metabolism in blunt snout bream fed a high-fat diet Fish Physiol Biochem 2017;43:1733-1745.

43 Lim L, Ebi I, Chor W, Kawamura G, Shapawi R: Determination on the possibility of dietary betaine supplementation to improve feed intake of soybean meal-based diet in the juvenile grouper (Epinephelus fuscoguttatus): A pilot study. Malays Appl Biol 2015;44:137-141. 


\section{Cellular Physiology Cell Physiol Biochem 2019;53:851-864 \begin{tabular}{l|l|l}
\hline DOI: 10.33594/000000177 & ( 2019 The Author(s). Published by
\end{tabular} and Biochemistry Published online: 13 November 2019 Cell Physiol Biochem Press GmbH\&Co. KG

44 Zakipour Rahimabadi E, Akbari M, Arshadi A, Effatpanah E: Effect of different levels of dietary Betaine on growth performance, food efficiency and survival rate of pike perch (Sander lucioperca) fingerlings. Iran J Fish Sci 2012;11:902-910.

45 Ghomi MR, Alizadehnajd A: Dietary lysine and methionine requirement of bream Abramis brama orientalis juvenile. Braz J Aquat Sci Technol 2012;16:79-82.

46 Salama M, H.EL-Abed F, El-Dahhar AA: Effect of Amino Acids (Lysine and Methionine + Cyctine) Supplementation Rate on Growth Performance and Feed Utilization of Sea Bass (Dentrarshus laborax) Larvae, in Journal of the Arabian Aquaculture Society, 2014, vol 8, pp 37-52.

47 Zhou F, Shao QJ, Xiao JX, Peng X, Ngandzali BO, Sun Z, Ng WK: Effects of dietary arginine and lysine levels on growth performance, nutrient utilization and tissue biochemical profile of black sea bream, Acanthopagrus schlegelii, fingerlings. Aquaculture 2011;319:72-80.

48 Small B, Soares J, Jr: Quantitative dietary lysine requirement of juvenile striped bass Morone saxatilis. Aquac Nutr 2000;6:207-212.

49 Berge G, Sveier H, Lied E: Effects of feeding Atlantic salmon (Salmo salar L.) imbalanced levels of lysine and arginine. Aquac Nutr 2002;8:239-248.

50 Lin S, Luo L: Effects of different levels of soybean meal inclusion in replacement for fish meal on growth, digestive enzymes and transaminase activities in practical diets for juvenile tilapia, Oreochromis niloticus $\times$ O. aureus. Anim Feed Sci Technol 2011;168:80-87.

51 Payne A, Wang X, Ivy M, Stewart A, Nelson K, Darris C, Nahashon S: Lysine mediation of neuroendocrine food regulation in guinea fowl. Poult Sci 2015;95:276-286.

52 Hevrøy E, El-Mowafi A, Taylor R, Olsvik P, Norberg B, Espe M: Lysine intake affects gene expression of anabolic hormones in Atlantic salmon, Salmo salar. Gen Comp Endocrinol 2007;152:39-46.

53 Kojima M, Hosoda H, Date Y, Nakazato M, Matsuo H, Kangawa K: Ghrelin is a growth-hormone-releasing acylated peptide from stomach. Nature 1999;402:656.

54 Gomes EF, Rema P, Kaushik SJ: Replacement of fish meal by plant proteins in the diet of rainbow trout (Oncorhynchus mykiss): digestibility and growth performance. Aquaculture 1995;130:177-186.

55 Vong Q, Chan K, Cheng C: Quantification of common carp (Cyprinus carpio) IGF-I and IGF-II mRNA by realtime PCR: differential regulation of expression by GH. J Endocrinol 2003;178:513-521.

56 Carew L, McMurtry J, Alster F: Effects of lysine deficiencies on plasma levels of thyroid hormones, insulin-like growth factors I and II, liver and body weights, and feed intake in growing chickens. Poult Sci 2005;84:1045-1050.

57 Espe M, Lemme A, Petri A, El-Mowafi A: Assessment of lysine requirement for maximal protein accretion in Atlantic salmon using plant protein diets. Aquaculture 2007;263:168-178.

58 Naz M, Turkmen M: Digestive enzymes and hormones in Gilthead Seabream Larvae (Sparus aurata) Fed Artemia Nauplii enriched with free histidine. Isr J Aquac 2008;60:230-236.

59 Chien YH, Pan CH, Hunter B: The resistance to physical stresses by Penaeus monodon juveniles fed diets supplemented with astaxanthin. Aquaculture 2003;216:177-191.

60 Lu J, Hua Y, Fu WZ, Zhou F, Yang BB, Xiao JX, Liu MH, Shao QJ: Effects of supplementation coated lysine and methionine in mixture protein diets on growth performance, digestibility and serum biochemical indices of juvenile Black Sea bream, Acanthopagrus schlegelii. Turk J Fish Aquat Sci 2014;14:633-642.

61 Alirezaei M, Niknam P, Jelodar G: Betaine elevates ovarian antioxidant enzyme activities and demonstrates methyl donor effect in non-pregnant rats. Int J Pept Res Ther 2012;18:281-290. 